\title{
PENGARUH EKSPEKTASI USAHA TERHADAP HEDONIC MOTIVATION, HABIT DAN NIAT PERILAKU PENGGUNAAN APLIKASI TRANSPORTASI ONLINE (Studi Pada Pelanggan Gojek Indonesia Di Kota Malang)
}

\author{
Ana Yuliana ${ }^{1}$, Endang Siti Astuti ${ }^{2}$, Tri Wulida Afrianty ${ }^{3}$ \\ Fakultas Ilmu Administrasi,Universitas Brawijaya, Malang, Indonesia ${ }^{123}$ \\ Email: anayuliana2807@gmail.com¹, endangsiti@ub.ac.id², twulidafia@ub.ac.id³
}

\begin{abstract}
The development of the internet which is integrated with the smartphone application technology has made the business of transportation service innovate by adopting online transportation applications. Online transportation applications are important to know whether the technology is really accepted by users. This paper provides literature for use as a reference in research into the acceptance and use of information technology with the UTAUT2 model. GOJEK is an online transportation application that provides solutions and convenience in daily activities. In fact, the desire to use the GOJEK application is not only because of the need for convenience, but also because of the urge to get pleasure and habits using the GOJEK application in daily activities. In proving the statement, this research builds a conceptual model and hypothesis formulation that is used to conduct research on the use of online transportation applications. This study will use sample of 130 customers who have used the GOJEK application for 1 or 3 months, then the data will be processed using PLS.
\end{abstract}

Keywords: Effort Expectancy, Hedonic Motivation, Habit, Behavior Intention, Transportation Application

\begin{abstract}
ABSTRAK
Perkembangan internet yang berintegrasi dengan teknologi aplikasi smartphone telah membuat dunia bisnis penyedia jasa transportasi melakukan inovasi dengan mengadopsi aplikasi transportasi online. Aplikasi transpotasi online penting untuk diketahui apakah teknologi tersebut benar-benar diterima oleh pengguna. Naskah ini menyediakan literature untuk digunakan sebagai acuan dalam penelitian penerimaan dan penggunaan teknologi informasi dengan model UTAUT2. GOJEK merupakan aplikasi transportasi online yang memberikan solusi dan kemudahan dalam kegiatan sehari-hari. Pada kenyataannya, keinginan untuk menggunakan aplikasi GOJEK bukan hanya karena kebutuhan akan kemudahan, tetapi juga karena dorongan untuk memperoleh kesenangan dan kebiasaan menggunakan aplikasi GOJEK dalam aktivitas sehari-hari. Dalam membuktikan pernyataan tersebut penelitian ini membangun model konseptual dan rumusan hipotesis yang digunakan untuk melakukan penelitian tentang penggunaan aplikasi transportasi online. Penelitian ini akan menggunakan sampel sebanyak 130 pelanggan yang telah menggunakan aplikasi GOJEK selama 1 atau 3 bulan, kemudian data akan diolah menggunakan PLS.
\end{abstract}

Kata Kunci: Ekspektasi Usaha, Hedonic Motivation, Habit, Niat Perilaku, Aplikasi Transpotasi 


\section{PENDAHULUAN}

Diketahui bahwa pengguna internet di Indonesia pada tahun 2018 mencapai lebih dari 171,176 juta pengguna atau setara dengan $64,8 \%$ dengan persentase pertumbuhan pengguna sebesar $10,12 \%$ dalam satu tahun (APJII, 2018). Internet diakses setiap hari melalui telepon pintar dengan persentase sebesar 93,9\% dari jumlah pengguna internet. Hasil survei terhadap pengguna internet menggambarkan bahwa terdapat banyak masyarakat yang telah memanfaatkan teknologi internet untuk kegiatan mereka. Berdasarkan informasi jumlah pengguna tersebut, terdapat banyak perusahaan yang menggunakan kesempatan tersebut untuk meningkatkan keunggulan dalam bersaing dengan mengembangkan aplikasi telepon pintar baik berupa produk maupun dalam bentuk jasa. Salah satu perusahaan yang dapat memanfaatkan peluang tersebut adalah perusahaan transportasi online di Indonesia.

Transportasi online merupakan salah satu bentuk inovasi terbaru dalam bidang layanan transportasi dan merupakan bagian dari layanan m-commerce yang dapat diartikan sebagai kegiatan transaksi dengan menggunakan mobile network (Silalahi, Handayani, \& Munajat, 2017). Transportasi online di Indonesia dapat diakses melalui telepon pintar dengan menggunakan internet. Data menurut comScore per Desember 2017 menunjukkan bahwa sebanyak 15,73 juta orang menggunakan aplikasi transportasi dan tercatat 9,7 juta pengunjung (unique visitors) mengakses GOJEK disusul oleh perusahaan transportasi online yang lainnya yaitu Grab sebanyak 9,6 juta orang (Cahya, 2018). Data tersebut menjelaskan bahwa minat masyarakat untuk menggunakan aplikasi transportasi online khususnya GOJEK tergolong cukup tinggi. GOJEK telah melakukan ekspansi hampir diseluruh kota di Indonesia, tidak terkecuali kota Malang.

Kota Malang dikenal sebagai salah satu kota pariwisata dan kota pendidikan di Indonesia, dimana setiap tahunnya tercatat banyaknya pendatang baik untuk menetap maupun untuk hanya sekedar berwisata. Badan Pusat Statistika mencatat jumlah migrasi sebanyak 22.117 orang dan 11.970 wisatawan mancanegara serta 4.335.975 wisatawan domestik (BPS Kota Malang, 2018).
Tabel 1. Migrasi Masuk dan Jumlah Wisatawan Kota Malang (Angka)

\begin{tabular}{|c|c|c|c|}
\hline Th. & $\begin{array}{c}\text { Jumlah } \\
\text { Migrasi }\end{array}$ & $\begin{array}{c}\text { Wisatawan } \\
\text { Mancanegara }\end{array}$ & $\begin{array}{c}\text { Wisatawan } \\
\text { Domestik }\end{array}$ \\
\hline 2016 & 22.117 & 9.535 & 3.987 .074 \\
\hline 2017 & 26.045 & 11.970 & 4.335 .975 \\
\hline
\end{tabular}

Sumber: Kota Malang Dalam Angka, 2018

Berdasarkan data tersebut, dapat diketahui bahwa kota Malang termasuk kota dengan angka pendatang yang tinggi di Indonesia. Pendatang di kota Malang akan membutuhkan layanan transportasi untuk mendukung aktivitas dan mobilitas yang tinggi. Hal ini dimanfaatkan oleh para pelaku bisnis transportasi tidak terkecuali oleh GOJEK sebagai salah satu penyedia jasa transportasi online. Transportasi online sangat bergantung dari aplikasi yang digunakan oleh pengguna karena aplikasi merupakan media yang menghubungkan pelanggan dengan penyedia jasa. Jika terdapat kendala dalam penggunaan aplikasi maka kegiatan bisnis dari transportasi online akan mengalami masalah. Sangat penting bagi perusahaan transportasi online untuk mengetahui bagaimana penggunaan aplikasi transportasi online dari sudut pandang pengguna khususnya oleh para pelanggan. Hal ini berkaitan dengan apakah teknologi tersebut digunakan atau tidak oleh pengguna. Sebagai sebuah bisnis, penting untuk mengetahui apakah aplikasi tersebut dapat diterima dan digunakan oleh penggunanya.

Seperti yang telah dijelaskan sebelumnya, bahwa aplikasi transportasi online merupakan sebuah inovasi teknologi yang dapat dikatakan baru bagi masyarakat. Sebuah teknologi akan berhasil jika dapat diterima dan digunakan oleh pengguna. Salah satu pengukur bahwa teknologi tersebut diterima dan digunakan adalah niat perilaku dari pengguna teknologi tersebut. Niat perilaku merupakan keinginan pengguna untuk menggunakan teknologi secara berulang dengan harapan pengguna mempunyai akses terhadap informasi (Venkatesh, Thong, \& Xu, 2012). Hasil penelitian yang telah meneliti tentang penerimaan dan penggunaan teknologi dengan menggunakan model UTAUT menyatakan beberapa hasil menunjukan hasil yang tidak sesuai dengan penelitian sebelumnya (ArenasGaitán, Peral-Peral, \& Ramón-Jerónimo, 2015; Baptista \& Oliveira, 2015; Herrero, San Martín, \& Garcia-De los Salmones, 2017; Morosan \& 
DeFranco, 2016). Ketidaksesuaian hasil penelitian tersebut menunjukkan bahwa dibutuhkan untuk melakukan penelitian kembali dengan menggunakan variabel yang berkaitan dengan model UTAUT2.

Aplikasi transportasi online membuktikan pencapaian aplikasi yang memberikan solusi dan kemudahan dalam kegiatan sehari-hari (http://www.cnbcindonesia.com, 2019). Pernyataan tersebut menjelaskan bahwa aplikasi transportasi online telah digunakan oleh masyarakat dalam berbagai kegiatan mereka. Pada kenyataannya, keinginan untuk menggunakan aplikasi bukan hanya kerena kebutuhan akan kemudahan saja, tetapi juga karena dorongan untuk memperoleh kesenangan dan terbentuknya sebuah kebiasaan menggunakan aplikasi dalam aktivitas seharihari. Hal ini dapat dilihat salah satunya dari pengguna harus selalu meng-update aplikasi agar dapat menggunakan semua fitur yang tersedia dan kegiatan tersebut dilakukan secara berulang-ulang sehingga pengguna terbiasa menggunakan aplikasi. Berdasarkan hal itu, adapun rumusan masalah dari penelitian ini adalah sebagai berikut:

1. Apakah ekspektasi usaha mempunyai pengaruh terhadap hedonic motivation?

2. Apakah ekspektasi usaha mempunyai pengaruh terhadap habit?

3. Apakah ekspektasi usaha mempunyai pengaruh terhadap niat perilaku?

4. Apakah hedonic motivation mempunyai pengaruh terhadap habit?

5. Apakah hedonic motivation mempunyai pengaruh terhadap niat perilaku?

6. Apakah habit mempunyai pengaruh terhadap niat perilaku?

\section{KAJIAN PUSTAKA}

\section{The Extended Unified Theory of Acceptance and Use of Technology (UTAUT2)}

The extended unified theory of acceptance and use of technology (UTAUT2) adalah sebuah model teori yang dikembangkan dari model yang sebelumnya yaitu UTAUT (Venkatesh et al., 2012). Jika pada awalnya UTAUT merupakan sebuah model penerimaan dan penggunaan teknologi yang befokus pada konteks organisasi, UTAUT2 merupakan pengembangan model yang mempunyai fokus terhadap consumer (konsumen). UTAUT2 meneliti tentang faktor-faktor yang berpengaruh terhadap niat penggunaan dan penggunaan teknologi yang baru (Venkatesh et al., 2012).

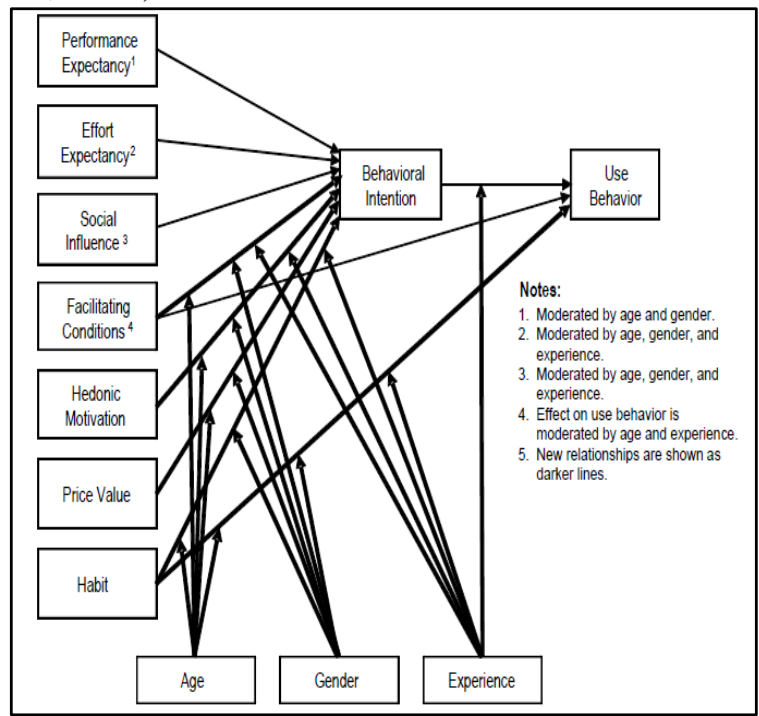

Gambar 2.The Extended Unified Theory of Acceptance and Use of Technology (UTAUT2) Sumber: Venkatesh et al., (2012)

Guna mengetahui apakah teknologi telepon pintar dan internet diterima dan digunakan oleh pengguna, terdapat salah satu model yang dapat digunakan yaitu model penerimaan dan penggunaan teknologi informasi yang dikenal dengan UTAUT (Unified Theory of Acceptance and Use of Technology). UTAUT (Unified Theory of Acceptance and Use of Technology) dikembangkan oleh Venkatesh et al., model ini dikembangkan untuk menguji tingkat adopsi teknologi yang didalamnya memberikan kemudahan pemahaman terhadap penerimaan dan penggunaan teknologi (Venkatesh et al., 2012). Model UTAUT merupakan kombinasi dari beberapa model dan teori yang telah dikembangkan sebelumnya, yaitu theory of reasoned action (TRA) (I. Ajzen \& Fishbein, 1980), theory of planned behaviour (TPB) (Icek Ajzen, 1988), technology acceptance model (TAM) (Davis, Bagozzi, \& Warshaw, 1989), diffusion of innovation theory (DOI) (Rogers, 1995), dan model kesuksesan sistem informasi D\&M (W. H. DeLone \& McLean, 2003; W. DeLone \& McLean, 1992).

Model UTAUT2 menambahkan beberapa variabel baru yang digunakan untuk mengukur niat perilaku dan penggunaan yaitu Hedonic Motivation, Habit, dan Price Value (Venkatesh et al., 2012). Penambahan tiga variabel baru dalam model UTAUT2 untuk mengatahui sebarapa besar rasa senang, manfaat, dan kebiasaan menggunakan 
teknologi yang dirasakan oleh pengguna. Dalam model UTAUT2, faktor-faktor ekspektasi, pengaruh sosial, kondisi pemfasilitasi, hedonic motivation, habit, dan price value menunjukkan adanya pengaruh yang signifikan terhadap niat perilaku dalam penggunaan teknologi (Venkatesh et al., 2012).

\section{Ekspektasi Usaha (Effort Expectancy)}

Ekspetasi usaha adalah harapan yang terkait dengan tingkat kemudahan dalam pemanfaatan sistem informasi (Venkatesh et al., 2003). Suatu sistem informasi dapat diadopsi dengan mudah, maka pengguna tidak perlu melakukan upaya yang tinggi. Sedangkan jika sistem informasi sulit untuk diadopsi, maka dibutuhkan upaya yang tinggi untuk menerapkan sistem tersebut. Ekspetasi usaha mempunyai dua konstruk yang terdapat didalam variabelnya adalah persepsi kemudahan penggunaan dan kerumitan/kompleksitas.

\section{Hedonic Motivation}

Istilah hedonic berasal dari kata
hedonisme yang digunakan untuk menunjukkan bahwa kesenangan atau kebahagiaan adalah hal yang utama dalam hidup (Merriam-Webster, 2003). Konteks hedonic dalam sistem informasi merupakan tingkat dimana pengalaman menyenangkan pengguna ketika menggunakan sistem informasi (Van Der Heijden, 2004). Hedonic motivation didefinisikan sebagai perasaan senang atau bahagia yang didapatkan dari penggunaan sebuah teknologi, dan memperlihatkan bahwa hal tersebut mempunyai peranan penting dalam faktor yang mempengaruhi penerimaan dan penggunaan teknologi (Venkatesh, et al., 2012). Dalam konteks konsumen dan penggunaan teknologi, semakin pengguna merasa senang dalam menggunakan sebuah teknologi maka pengguna akan mempunyai niat yang tinggi dalam menggunakan sebuah teknologi.

\section{Habit}

Habit diartikan sebagai sejauh mana seseorang cenderung melakukan perilaku secara otomatis yang disebabkan karena belajar (Limayem et al., 2007). Habit dibagi menjadi dua konseptualisasi, pertama habit dipandang sebagai perilaku sebelumnya (Malhotra \& Birks, 2007). Kedua, habit diukur sebagai sejauh mana habit menjadi sebuah perilaku individu (Limayem et al., 2007). Habit dianggap sebagai prediktor yang baik untuk mengukur niat perilaku dalam penggunaan teknologi.

\section{Behavioral Intention (Niat Perilaku)}

Niat merupakan keinginan yang menjadi kecenderungan yang dimiliki seseorang untuk melakukan perilaku tertentu (Fishbein and Ajzen, 1975). Niat akan tetap menjadi kecenderungan berperilaku sampai terdapat usaha untuk mengubah niat menjadi sebuah perilaku (Ajzen \& Fishbein, 2005). Dalam konteks teknologi informasi niat perilaku (behavioral intention) diartikan sebagai keinginan atau niat yang dimiliki oleh pemakai untuk menggunakan sebuah sistem informasi secara berulang dengan harapan bahwa pengguna mempunyai akses terhadap informasi (Venkatesh et al., 2003). Seorang pengguna mempunyai minat menggunakan sebuah sistem informasi jika pengguna menyakini bahwa dengan menggunakan sistem informasi tersebut akan meningkatkan produktivitas.

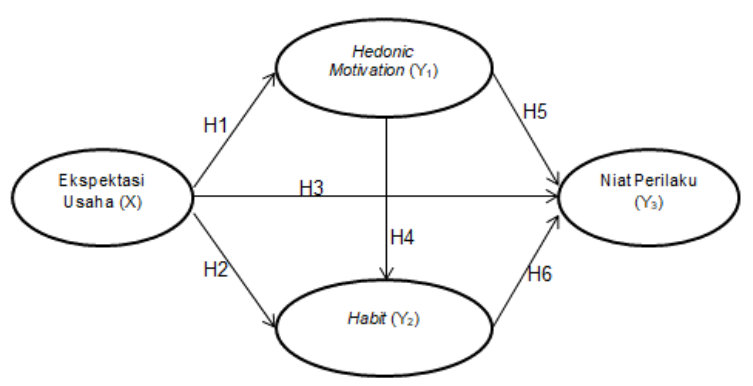

Gambar 1. Model Hipotesis Penelitian

\section{Ekspektasi Usaha dan Hedonic Motivation}

Ekspektasi usaha dalam konteks penerimaan dan penggunaan teknologi informasi dibentuk berdasarkan tiga konstruk yang mempunyai persamaan tentang mudah atau tidaknya sebuah teknologi digunakan. Pertama, kemudahan penggunaan persepsian (perceived easy of use) dalam model penerimaan teknologi (Technology Acceptance Model) yang diartikan sebagai seberapa jauh seseorang percaya bahwa menggunakan suatu teknologi, maka seseorang tersebut akan terbebas dari suatu usaha (Davis et al., 1989). Kedua, kerumitan (complexity) dalam Model of $P C$ utilization (MPCU) yang berkaitan dengan 
persepsi semakin kompleks sebuah teknologi yang digunakan maka secara relatif teknologi tersebut akan susah untuk dipahami (Thompson et al., 1991). Ketiga, kemudahan penggunaan dalam innovation diffusion theory, dimana suatu inovasi dipersepsikan sebagai sesuatu yang sulit untuk digunakan (Moore and Benbasat, 1991). Kepercayaan yang ditimbulkan bahwa kemudahan dalam menggunakan sebuah teknologi dapat mengurangi upaya pengguna dalam melakukan aktivitas (Venkatesh et al., 2012).

Dalam beberapa penelitian empiris, kemudahan penggunaan (easy of use) dikaitkan dengan kesenangan (Di Pietro et al., 2012; Herrero et al., 2017; Lowry et al., 2013). Sejalan dengan konteks bahwa perilaku konsumen dibedakan menjadi dua yaitu utilitarian dan hedonis, maka hal tersebut berlaku dalam penggunaan teknologi (Brown and Venkatesh, 2005). Hedonisme yang digunakan untuk menunjukkan bahwa kesenangan adalah tujuan utama dalam hidup, penggunaan teknologi secara hedonis bertujuan untuk mencari kesenangan. Persepsi kemudahan penggunaan mempunyai pengaruh positif terhadap kesenangan dalam penggunaan teknologi, dimana hal ini disebut dengan motivasi hedonis contohnya tujuan utama penggunaan teknologi adalah untuk memenuhi motivasi intrinsik pengguna. Hal ini didukung dengan adanya hasil empiris Herrero et al. (2017) yang membuktikan bahwa ekspektasi usaha mempunyai pengaruh terhadap hedonic motivation. Penelitian dilakukan pada pengguna situs social networking dengan sampel penelitian 537 wisatawan yang menggunakan situs social network untuk membagikan pengalaman mereka. Berdasarkan penjelasan diatas maka hipotesis penilitian ini adalah sebagai berikut:

H1: Ekspektasi usaha (X) mempunyai pengaruh terhadap hedonic motivation $\left(\mathrm{Y}_{1}\right)$.

\section{Hubungan Ekspektasi Usaha dan Habit}

Habit dalam konsep penerimaan dan penggunaan teknologi tidak dapat dipisahkan dengan pengalaman yang diperoleh pengguna ketika menggunakan teknologi (Venkatesh et al., 2012). Pengalaman yang menyenangkan merupakan pengembangan kebiasaan karena hal tersebut dapat meningkatkan kecenderungan seseorang untuk mengulangi tindakan yang sama berulang kali (Aarts et al.,
1997). Habit (kebiasaan) terbentuk dari tindakan yang dilakukan secara berulang. Dalam penggunaan teknologi, keinginan pengguna untuk terus menggunakan teknologi ditentukan oleh apakah teknologi tersebut sesuai dengan harapan awal pengguna yaitu sejauh mana teknologi tersebut mudah digunakan (Bhattacherjee, 2001; Wixom and Todd, 2005). Oleh karena itu, pengguna internet cenderung loyal kepada situs web yang menawarkan pengalaman yang menyenangkan karena situs web menawarkan kemudahan dalam penggunaannya (Herrero et al., 2017). Sebaliknya, jika penggunaan suatu teknologi dikaitkan dengan pengalaman yang tidak menyenangkan bahkan cenderung membuat frustasi, pengguna akan berhenti menggunakan dan tidak pernah mengembangkan kebiasaan dalam menggunakan teknologi tersebut (Pillet and Carillo, 2016).

Belum banyak studi empiris yang melakukan penelitian tentang pengaruh ekspektasi usaha terhadap habit. Herrero et al., (2017) membuktikan bahwa ekspektasi usaha dalam menggunakan situs social network mempunyai pengaruh yang signifikan terhadap habit. Penelitian lain juga menjelaskan bahwa kemudahan penggunaan dalam teknologi social collaboration dalam kebiasaan yang dimiliki oleh para pekerja dibidang ilmu pengetahuan (Pillet and Carillo, 2016). Berdasarkan penjelasan diatas maka hipotesis penilitian ini adalah sebagai berikut:

$\mathrm{H}$ 2: Ekspektasi usaha (X) mempunyai pengaruh terhadap habit $\left(\mathrm{Y}_{2}\right)$.

\section{Hubungan Ekspektasi Usaha dan Niat Perilaku}

Salah satu teori yang dapat menjelaskan pengaruh ekspektasi usaha terhadap niat perilaku adalah teori perilaku interpersonal (theory of interpersonal behavior). Theory of interpersonal behavior dikembangkan oleh Triandis (1980). Dalam teori tersebut mengusulkan bahwa niat-niat perilaku salah satunya ditentukan oleh konsekuensi ekspektasi (expected consequences) dari sebuah perilaku. Konsekuensi ekspektasi didefinisikan menjadi tiga dimensi, dua dari tiga dimensi berhubungan dengan waktu jangka pendek dan satu dimensi berhubungan dengan jangka panjang (Thomson dan Higgins, 1991). Dalam penggunaan teknologi informasi dimensi yang berhubungan dengan jangka pendek adalah 
persepsi tentang kerumitan, dimana kerumitan mempunyai kemiripan dengan konsep kemudahan penggunaan yang terdapat pada model penerimaan teknologi sedangkan kerumitan merupakan kebalikan dari kemudahan penggunaan (Davis et al., 1989; Thompson et al., 1991).

Persepsi kerumitan dan kemudahan penggunaan sebuah teknologi merupakan konstruk yang digunakan oleh Venkatesh et al., (2003) untuk membangun sebuah konstruk ekspektasi usaha dalam teori penerimaan dan penggunaan teknologi. Ekspektasi usaha merupakan tingkat kemudahan menggunakan sebuah teknologi yang diukur melalui mudah atau tidaknya penggunaan sebuah teknologi (Venkatesh et al,. 2003; 2012). Kemudahan dalam penggunaan sebuah teknologi akan menimbulkan keinginan untuk menggunakan teknologi yang sama diwaktu yang akan datang. Terdapat beberapa penelitian yang telah membuktikan bahwa ekspektasi usaha mempengaruhi niat perilaku pengguna teknologi. Chopdar et al., (2018) melakukan penelitian tentang adopsi aplikasi mobile shopping yang dilakukan di India dan hasil penelitian menunjukkan bahwa ekspektasi usaha berpengaruh signifikan terhadap niat perilaku. Dalam adopsi mobile banking, ekspektasi usaha juga terbukti mempunyai pengaruh yang signifikan tehadap niat perilaku (Arenas et al., 2015; Alalwan et al., 2017). Berdasarkan penjelasan diatas maka hipotesis penilitian ini adalah sebagai berikut:

H3: Ekspektasi usaha (X) mempunyai pengaruh terhadap niat perilaku $\left(\mathrm{Y}_{3}\right)$.

\section{Hubungan Hedonic Motivation dan Habit}

Pengaruh hedonic motivation terhadap habit dapat dijelaskan dengan nilai yang dirasakan dianggap sebagai evaluasi keseluruhan individu tentang kegunaan suatu kegiatan berdasarkan pada persepsi mereka tentang apa yang diterima dan apa yang diberikan (Chircu and Mahajan, 2006; Zeithaml, 1988). Dalam konteks penerimaan dan penggunaan teknologi informasi, nilai yang dirasakan adalah manfaat yang dirasakan dari penggunaan sebuah teknologi serta waktu dan usaha yang dikeluarkan oleh pengguna. Dalam banyak penelitian tentang motivasi menunjukkan bahwa pertimbangan nilai yang memotivasi orang untuk terlibat dalam perilaku tertentu memiliki dimensi utilitarian dan hedonis (Babin et al., 1994). Nilai utilitarian mencerminkan bahwa sesuatu diperoleh dengan cara yang efisien dan dapat dipandang sebagai hasil dari kegiatan yang lebih berorientasi pada tugas, kognitif, dan nonemosional (Babin et al., 1994; Hirschman and Holbrook, 1982). Sedangkan Nilai hedonis mencerminkan nilai yang diterima dari aspek multisensor, fantasi, dan emotif dari pengalaman (Hirschman and Holbrook, 1982).

Bridge dan Florsheim mengidentifikasi nilai utilitarian dan hedonis sebagai tujuan sedangkan Aarts dan Dijksterhuis berpendapat bahwa hal tersebut dapat secara langsung menyebabkan terjadinya kebiasaan dan semakin tinggi nilai yang dirasakan, semakin besar kemungkinan menjadi sebuah kebiasaan (Aarts and Dijksterhuis, 2000; Bridges and Florsheim, 2008). Dalam konteks penggunaan teknologi, hal tersebut menggambarkan bahwa untuk meningkatkan sebuah kebiasaan dalam menggunakan sebuah teknologi, pengguna perlu mendapatkan sebuah nilai-nilai termasuk nilai utilitarian dan nilai hedonis.

Kebiasaan menggunakan teknologi juga terkait dengan motivasi hedonis. Secara khusus motivasi hedonis dalam penggunaan teknologi secara langsung mempengaruhi kebiasaan (habit) menggunakan dan melalui sebuah kebiasaan akan mempengaruhi niat untuk menggunakan teknologi tersebut dimasa yang akan datang (Chiu et al., 2012). Oleh karena itu, persepsi pengguna tentang kesenangan dan kenyamanan dalam penggunaan teknologi mempunyai terhadap habit (kebiasaan) penggunaan teknologi (Herrero et al., 2017). Hal ini dibuktikan Herrero et al., (2017) bahwa hedonic motivation berpengaruh signifikan terhadap habit. Dengan kata lain, jika pengguna memiliki motivasi hedonis yang kuat dalam penggunaan sebuah teknologi, maka akan meningkatkan kebiasaan dalam penggunaan teknologi tersebut. Berdasarkan penjelasan diatas maka hipotesis penilitian ini adalah sebagai berikut:

H4: Hedonic motivation ( $\left.\mathrm{Y}_{1}\right)$ mempunyai pengaruh terhadap habit $\left(\mathrm{Y}_{2}\right)$.

\section{Hubungan Hedonic Motivation dan Niat Perilaku}

Pengaruh motivasi hedonis pada niat perilaku terjadi karena perbedaan inovasi konsumen, pencarian terhadap hal yang baru, 
dan persepsi kebaruan terhadap teknologi (Venkatesh et.al., 2012). Inovasi dan pencarian terhadap hal yang baru dapat meningkatkan motivasi hedonis untuk menggunakan produk apapun (Holbrook and Hirschman, 1982). Ketika konsumen mulai menggunakan teknologi tertentu, mereka akan lebih memperhatikan kebaruan dan bahkan dapat menggunakannya untuk hal yang baru. Dalam konteks penggunaan teknologi informasi oleh konsumen secara umum, manfaat hedonis adalah pendorong penting penggunaan teknologi (Venkatesh et al., 2012). Hedonis dalam penggunaan teknologi telah tersebar diseluruh konsumen teknologi, motivasi hedonis memainkan peran penting dalam memprediksi niat untuk menggunakan teknologi informasi.

Teori yang digunakan untuk menjelaskan pengaruh hedonic motivation terhadap niat perilaku dapat dijelaskan melalui Unified Theory of Acceptance and Use of Technology (UTAUT). Hedonic motivation adalah perasaan senang dan kenyamanan yang didapatkan dari penggunaan sebuah teknologi (Venkatesh et al., 2012). Pengguna sebuah sistem informasi akan mempunyai keinginan yang tinggi untuk menggunakan sistem informasi jika pengguna merasakan perasaan senang ketika penggunaan menggunakan sistem informasi tersebut. Pengaruh hedonic motivation terhadap niat perilaku menggunakan ditemukan dalam pembelian tiket pesawat secara online melalui situs web (Escobar and Carvajal, 2014). Hal tersebut menunjukkan bahwa rasa senang dan nyaman yang didapatkan oleh pengguna ketika menggunakan situs web membuat pengguna berkeinginan untuk membeli tiket dengan menggunakan situs web yang sama di waktu yang akan datang. Hasil empiris yang sama juga ditunjukkan dalam pengadopsian mobile banking (Arenas et al., 2015; Baptista and Oliveira, 2015; Alalwan et al., 2017). Berdasarkan penjelasan diatas maka hipotesis penilitian ini adalah sebagai berikut:

H5: Hedonic motivation ( $\left.\mathrm{Y}_{1}\right)$ mempunyai pengaruh terhadap niat perilaku $\left(\mathrm{Y}_{3}\right)$.

\section{Hubungan Habit dan Niat Perilaku}

Theory of interpersonal yang mengusulkan bahwa niat perilaku di tentukan oleh perasaan yang dimiliki oleh manusia terhadap perilaku yang dilakukan, apa yang mereka pikirkan tentang yang seharusnya dilakukan, dan dipengaruhi oleh konsekuensi dari berbagai ekspektasi dari perilaku (Triandis, 1980). Dimana selanjutnya perilaku dipengaruhi oleh apa yang biasa dilakukan oleh manusia yang disebut dengan kebiasaan (habit). Dalam konteks penerimaan dan penggunaan teknologi, habit mempunyai keterkaitan dengan pengalaman (Venkatesh et al., 2012). Seseorang akan terbiasa menggunakan teknologi dalam kurun waktu tertentu dan hal tersebut akan mempengaruhi keinginan untuk menggunakan kembali teknologi yang telah digunakan. Hal tersebut dibuktikan oleh Herrero et al., (2017) yang menjelaskan bahwa kebiasaan (habit) mendahului niat perilaku dalam pengadopsian situs social network.

Hasil empiris yang mendukung adanya pengaruh habit terhadap niat perilaku juga ditunjukkan dalam penelitian tentang adopsi aplikasi smartphone (Gupta et al., 2018). Penelitian menunjukkan bahwa habit mempunyai pengaruh yang signifikan terhadap niat adopsi aplikasi travel oleh wisatawan. Pengaruh habit terhadap niat perilaku juga ditunjukkan dalam adopsi pembayaran yang dilakukan melalui aplikasi smartphone (Mahendra et al., 2017). Dalam penelitian ditemukan bahwa habit merupakan factor yang paling berpengaruh terhadap niat perilaku, hal ini ditunjukkan dengan habit mempunyai nilai pengaruh paling tinggi dibandingkan dengan factor-faktor yang lain.

Berdasarkan penjelasan diatas maka hipotesis penilitian ini adalah sebagai berikut:

H6: Habit $\left(\mathrm{Y}_{2}\right)$ mempunyai pengaruh terhadap niat perilaku $\left(\mathrm{Y}_{3}\right)$.

\section{METODE PENELITIAN}

Penelitian ini akan mengambil sampel sebanyak 130 responden. Teknik sampling yang digunakan adalan purposive sampling dengan kriteria bahwa responden menggunakan aplikasi GOJEK minimal 1 bulan dan atau lebih. Metode yang akan digunakan dalam pengumpulan data adalah dengan menyebar kuesioner secara daring yang akan diisi oleh pelanggan GOJEK dikota Malang. Data yang diperoleh selanjutnya akan di olah menggunakan PLS.

\section{KESIMPULAN DAN SARAN Kesimpulan}

Pergeseran kebutuhan akan teknologi internet yang semakin berkembang telah 
merambah kepeda seluruh bidang tak terkecuali bidang peyedia jasa transportasi online. Transportasi online adalah gabungan dari aplikasi dari smartphone yang dapat diakses oleh pengguna dengan adanya integrasi antara aplikasi, smartphone dan internet. Pentingnya penggunaan aplikasi transpotasi online, perlu dipastikan apakah aplikasi diterima dan digunakan oleh konsumen. Terdapat satu model untuk mengetahui apakah teknologi tersebut diterima dan digunakan oleh pengguna yaitu UTAUT2 (Unified theory of acceptance and use of technology).

Model UTAUT2 menunjukkan bahwa Behavior Intention (Niat Perilaku) dipengaruhi oleh persepsi pengguna terhadap Performance Expectancy (Ekspektasi Kinerja), Effort Expetancy (Ekspektasi Usaha), dan Social Influence (Pengaruh Sosial), Hedonic Motivation, Habit, dan Price Value. Model UTAUT2 juga menjelaskan Use Behaviour (perilaku mengggunakan) suatu sistem informasi dipengaruhi oleh Behavior Intention (Niat Perilaku) dan Facilitating Conditions (Kondisi Pemfasilitasi). Persepsi pada model ini juga dimoderasi oleh Jenis Gender (Kelamin), Age (Umur), Experience (Pengalaman), dan Voluntariness (Kesukarelaan).

Variabel yang digunakan dalam penelitian ini adalah ekspektasi usaha (effort expectancy), Hedonic Motivation, Habit, dan Niat perilaku (Behavioral Intention). Hubungan yang ditunjukkan oleh antar variabel adalah jika pengguna merasa percaya bahwa dengan menggunakan sebuah teknologi dapat meningkatkan sebuah harapan, sehingga niat perilaku penggunaan teknologi akan meningkat. Penelitian ini meneliti pelanggan aplikasi GOJEK di kota malang yang telah mengakses aplikasi lebih dari 1 bulan. Jumlah sampel yang akan digunakan dalam penelitian ini adalah 130 responden dengan teknik purposive sampling.

\section{Saran}

Penelitian ini membutuhkan banyak saran dan masukkan untuk lebih baik dalam penelitian yang akan dilakukan. Guna mengembangkan penelitian, saran untuk penelitian yang akan datang, dapat menambahkan variabel moderasi sesuai dengan model penerimaan dan penggunaan teknologi informasi yaitu jenis kelamin, umur, dan pengalaman responden.

\section{DAFTAR PUSTAKA}

Aarts, H., Paulussen, T., \& Schaalma, H. (1997). Physical exercise habit: On the conceptualization and formation of habitual health behaviours. Health Education Research. https://doi.org/10.1093/her/12.3.363

Ajzen, I., \& Fishbein, M. (1980). Understanding attitudes and predicting social behaviour. Integration (Tokyo, Japan), (40), 27-29. https://doi.org/Z

Ajzen, Icek. (1988). Attitudes, personality, and behavior. 1988. Milton Keynes: Open University Press Google Scholar. https://doi.org/10.1037/e418632008-001

Alalwan, A. A., Dwivedi, Y. K., \& Rana, N. P. (2017). Factors influencing adoption of mobile banking by Jordanian bank customers: Extending UTAUT2 with trust. International Journal of Information Management, 37(3), 99-110. https://doi.org/10.1016/j.ijinfomgt.2017.0 1.002

Arenas-Gaitán, J., Peral-Peral, B., \& RamónJerónimo, M. A. (2015). Elderly and internet banking: An application of UTAUT2. Journal of Internet Banking and Commerce, 20(1). https://doi.org/10.1007/978-3-53192534-9_12

Asosiasi Penyelenggara Jasa Internet Indonesia. (2018). Infografis Penetrasi \& Perilaku Pengguna Internet Indonesia. Teknopreuner.

Baptista, G., \& Oliveira, T. (2015). Understanding mobile banking: The unified theory of acceptance and use of technology combined with cultural moderators. Computers in Human Behavior, 50, 418-430. https://doi.org/10.1016/j.chb.2015.04.024

Bhattacherjee, A. (2001). Understanding information systems continuance: An expectation-confirmation model. MIS Quarterly: Management Information Systems. https://doi.org/10.2307/3250921

BPS Kota Malang. (2018). Ht Tp $S$ : // M Al a Ng Ko T B Ps Ht Tp $S$ : Al Ko T B.

Cahya, P. (2018). 10 E-Commerce Terbaik yang Menggeser Eksistensi Toko Offline.

Chopdar, P. K., Korfiatis, N., Sivakumar, V. J., 
\& Lytras, M. D. (2018). Mobile shopping apps adoption and perceived risks: A cross-country perspective utilizing the Unified Theory of Acceptance and Use of Technology. Computers in Human Behavior.

https://doi.org/10.1016/j.chb.2018.04.017

DailySocial id. (2018). Startup Report. In DailySocial.

Davis, F. D., Bagozzi, R. P., \& Warshaw, P. R. (1989). User Acceptance of Computer Technology: A Comparison of Two Theoretical Models. Management Science, 35(8), 982-1003. https://doi.org/10.1287/mnsc.35.8.982

DeLone, W. H., \& McLean, E. R. (2003). The DeLone and McLean model of information systems success: A ten-year update. Journal of Management Information Systems. https://doi.org/10.1080/07421222.2003.1 1045748

DeLone, W., \& McLean, E. (1992). Information System Success: The Quest for the Dependent Variable. Information Systems Research, 3(1), 60-65. https://doi.org/10.1287/isre.3.1.60

Escobar-Rodríguez, T., \& Carvajal-Trujillo, E. (2014). Online purchasing tickets for low cost carriers: An application of the unified theory of acceptance and use of technology (UTAUT) model. Tourism Management, 43, 70-88. https://doi.org/10.1016/j.tourman.2014.0 1.017

Gupta, A., Dogra, N., \& George, B. (2018). What determines tourist adoption of smartphone apps?: An analysis based on the UTAUT-2 framework. Journal of Hospitality and Tourism Technology. https://doi.org/10.1108/JHTT-02-20170013

Herrero, Á., San Martín, H., \& Garcia-De los Salmones, M. del M. (2017). Explaining the adoption of social networks sites for sharing user-generated content: A revision of the UTAUT2. Computers in Human Behavior, 71, 209-217. https://doi.org/10.1016/j.chb.2017.02.007

Isaac, O., Abdullah, Z., Ramayah, T., \& Mutahar, A. M. (2017). Internet Usage and Net Benefit among Employees Within Government Institutions in Yemen: An Extension of Delone and Mclean Information Systems Success Model
(DMISM) with Task-Technology Fit. International Journal of Soft Computing, 12(3), 178-198.

https://doi.org/10.3923/ijscomp.2017.178 .198

Mahendra, Y. A. S., Winarno, W. W., \& Santosa, P. I. (2017). Pengaruh Perceived Security terhadap Pengadopsian In-App Purchase pada Aplikasi Mobile. Jurnal Nasional Teknik Elektro Dan Teknologi Informasi (JNTETI). https://doi.org/10.22146/jnteti.v6i2.313

Moore, G. C., \& Benbasat, I. (1991). Development of an instrument to measure the perceptions of adopting an information technology innovation. Information SystemsResearch. https://doi.org/10.1287/isre.2.3.192

Morosan, C., \& DeFranco, A. (2016). It's about time: Revisiting UTAUT2 to examine consumers' intentions to use NFC mobile payments in hotels. International Journal of Hospitality Management, 53, 17-29. https://doi.org/10.1016/j.ijhm.2015.11.00 3

Pillet, J. C., \& Carillo, K. D. A. (2016). Emailfree collaboration: An exploratory study on the formation of new work habits among knowledge workers. International Journal of Information Management. https://doi.org/10.1016/j.ijinfomgt.2015.1 1.001

Rogers, E. M. (1995). Elements of Diffusion. Diffusion of Innovations. https://doi.org/10.1007/978-94-0109292-0

Silalahi, S. L. B., Handayani, P. W., \& Munajat, Q. (2017). Service Quality Analysis for Online Transportation Services: Case Study of GO-JEK. Procedia Computer Science, 124,487-495. https://doi.org/10.1016/j.procs.2017.12.1 81

Venkatesh, V., Morris, M. G., Davis, G. B., \& Davis, F. D. (2003). User Acceptance of Information Technology: Toward a unified view. MIS Quarterly, 27(3), 425478.

https://doi.org/10.1017/CBO9781107415 324.004

Venkatesh, V., Thong, J., \& Xu, X. (2012). Consumer Acceptance and User of Information Technology: Extending the Unified Theory of Acceptance and Use of Technology. MIS Quarterly, 36(1), 157- 
178. https://doi.org/10.1111/j.13652729.2006.00163.x

Wixom, B. H., \& Todd, P. A. (2005). A theoretical integration of user satisfaction and technology acceptance. Information SystemsResearch.

https://doi.org/10.1287/isre.1050.0042 